\title{
The efficacy and safety of vildagliptin treatment for nonalcoholic fatty liver disease in type 2 diabetes mellitus
}

\section{Non alkolik yağlı karaciğer hastalığ|ı olan tip 2 dilyabetes mellitus'ta vildagliptin tedavisinin etkinliği ve güvenliği}

\author{
Aktaş Ahmet', Ozan Zeynep Tuğba²
}

${ }^{1}$ Department of Internal Medicine, Faculty of Medicine, Cumhuriyet University, Sivas, Turkey

${ }^{2}$ Department of Internal Medicine, Faculty of Medicine, Bozok University, Yozgat, Turkey

Corresponding author: Aktaş Ahmet, MD, Department of Internal Medicine, Faculty of Medicine, Cumhuriyet University, Sivas, Turkey

E-mail: ahmetaktas0142@hotmail.com

Received/Accepted: December 03, 2020 /December 17, 2020

Conflict of interest: There is not a conflict of interest.

\section{SUMMARY}

Objective: Effects of dipeptidyl peptidase-4 inhibitors on liver function and glucose metabolism in nonalcoholic fatty liver disease (NAFLD) have not been well determined. The aim of this study was to evaluate the effect of vildagliptin on liver functions and hepatic steatosis and also to evaluate efficacy and safety of vildagliptin in NAFLD patients with type 2 diabetes mellitus (DM).

Method: Fifty-four patients with type 2 DM, complicated with ultrasonography (USG) diagnosed NAFLD were prospectively enrolled in the study from June 2014 to June 2015 in Bozok University Hospital. All patients were subjected to lifestyle intervention of diet and physical exercise after the diagnosis of type 2 DM. Vildaliptin treatment was given $100 \mathrm{mg}$ per day. Liver non-invasive assessment tools such as, Fatty Liver Index (FLI), FIB-4 index, APRI Score, and other laboratory parameters were also evaluated before, 3 and 6 months after the initiation of treatment.

Results: HbA1c was reduced from $9.22 \%(8.07-10.35)$ to $7.26 \%(6.27$ 8.10) $(\mathrm{P}<0.001)$. During vildagliptin treatment, ALT levels improved from $30.91 \pm 26.48$ to $25.94 \pm 14.8 \mathrm{IU} / \mathrm{L}(\mathrm{P}<0.05)$. The serum levels of TG and LDL decreased with statistical significance $(\mathrm{P}<0.05)$. WC and BMI were also decreased $(\mathrm{P}<0.001)$. FLI and APRI scores improved at 6 months after the initiation of vildagliptin $(\mathrm{P}<0.05)$. Patients showed improvement for fatty liver severity by USG after vildagliptin treatment $(\mathrm{P}<0.001)$. All the patients took vildagliptin of $100 \mathrm{mg} /$ day without reduction necessitated by related side-effects.

Conclusions: Our preliminary study results showed that vildagliptin treatment have positive effect on blood sugar regulation, body composition, ALT, liver fibrosis and steatosis indexes in type $2 \mathrm{DM}$ complicated with NAFLD. Vildagliptin seems to be effective and safe in NAFLD patients with type 2 DM.

Keywords: Vildagliptin; hepatic steatosis; liver functions; liver fibrosis indexes
Aktaş Ahmet

(D) Ozan Zeynep Tuğba

ORCID IDs of the authors: A.A. $0000-0001-9464-0700$ O.Z.T. 0000-0002-4654-8982 
Amaç: Dipeptidil peptidaz-4 inhibitörlerinin Non Alkolik Yağlı Karaciğer Hastalığında (NAYKH) karaciğer fonksiyonu ve glikoz metabolizması üzerindeki etkileri iyi belirlenmemiştir. Bu çalı̧̧manın amacı, vildagliptinin karaciğer fonksiyonları ve hepatik steatoz üzerindeki etkisini değerlendirmek ve ayrıca tip 2 diabetes mellitus (DM) olan NAYKH hastalarında vildagliptinin etkililiğini ve güvenliğini değerlendirmektir.

Yöntem: Bozok Üniversitesi Hastanesinde Haziran 2014 - Haziran 2015 tarihleri arasında ultrasonografi ile NAYKH tanısı konulan tip 2 DM' li 54 hasta çalışmaya alındı. Tüm hastalara tip 2 DM tanısı konulduktan sonra yaşam tarzı diyet ve fiziksel egzersiz müdahalesi uygulandı. Vildaliptin tedavisi günde $100 \mathrm{mg}$ verildi. Yağlı Karaciğer İndeksi (FLI), FIB4 indeksi, APRI Skoru gibi karaciğerin non-invaziv değerlendirme araçları ve diğer laboratuvar parametreleri tedavi öncesi, tedavi başladıktan 3 ve 6 ay sonra değerlendirildi.

Bulgular: HbA1c,\% 9.22'den (8.07-10.35)\% 7.26'ya (6.27-8.10) düşürüldü ( $\mathrm{P}<0.001)$. Vildagliptin tedavisi sırasında, ALT seviyeleri $30.91 \pm 26.48$ 'den $25.94 \pm 14.8$ IU / L'ye geriledi $(\mathrm{P}<0.05)$. Serum TG ve LDL seviyeleri istatistiksel anlamlılıkla azaldı $(\mathrm{P}<0.05)$. Bel çevresi ve vücut kitle indeksi de azaldı $(\mathrm{P}<0.001)$. FLI ve APRI skorları, vildagliptin başlangıcından 6. ayda düzeldi ( $\mathrm{P}<0.05)$. Hastalar, vildagliptin tedavisinden sonra USG ile yağlı karaciğer şiddeti için iyileşme gösterdi ( $\mathrm{P}<0.001)$. Tüm hastalar, ilgili yan etkilerin gerektirdiği azalma olmaksızın $100 \mathrm{mg} /$ gün vildagliptin almıştır.

Sonuç: Ön çalışma sonuçlarımız, NAYKH olan tip 2 DM'de vildagliptin tedavisinin kan şekeri regülasyonu, vücut kompozisyonu, ALT, karaciğer fibrozu ve steatoz indeksleri üzerinde olumlu etkisi olduğunu göstermiş̧tir. Vildagliptin, tip 2 DM'li NAYKH hastalarında etkili ve güvenli görünmektedir.

Anahtar sözcükler: Vildagliptin; hepatik steatoz; karaciğer fonksiyonları; karaciğer fibrozis indeksleri

\section{INTRODUCTION}

Nonalcoholic fatty liver disease (NAFLD) is the most common chronic liver disease in developed countries. The clinical significance of is; common occurrence in the community and its potential to progress to end-stage liver disease ${ }^{1}$. Treatment modalities are evaluated to prevent the progression of the disease or will act as anti-fibrotic agent. Incretin hormone therapies and their extra pancreatic effects are currently the subject of researches especially in NAFLD as we know that in the pathogenesis of NAFLD, insulin resistance and lipid peroxidation is accused vigorously and the majority of patients with type 2 diabetes also has the entity of NAFLD ${ }^{2}$.

Dipeptidyl peptidase IV (DPP IV) is a serine amino exopeptidase that play an important role in the balance of plasma glucose levels with degradation of incretin peptide hormones glucagon-like peptide-1 (GLP-1) and glucose-dependent insulinotropic polypeptide $(\mathrm{GIP})^{3}$. Controlling diabetes with the inhibition of this enzyme is one of the strategies adopted in recent years. Vildagliptin; as a potent and long lasting DPP-4 inhibitor (DPP IV-I), stimulates the plasma insulin concentrations and also decreases postprandial triglyceride levels which can result with a decrease in liver triglyceride concentration so improves fatty liver ${ }^{4,5}$. Vildagliptin was also shown to increase glucose utilization at the high dose of insulin (80 $\mathrm{mu})$. This potential effect may be secondary to a reduction in liver fat 6, 7. Reducing insulin resistance, regulating DPP4 activity directly associated with fatty liver, anti-inflammatory or anti-oxidant effects are known to be the positive pathophysiological mechanisms of DPP4 inhibitors .

Although the beneficial effect of DPP-4 inhibition on DM is identified; the effects of these drugs on liver inflammation, fibrosis and the progression of the disease still open for discussion in NAFLD. The purpose of this study is to evaluate the effects of vildagliptin on liver enzymes, hepatic steatosis and fibrosis. We also to evaluate the efficacy and safety of vildagliptin in NAFLD patients with type 2 DM.

\section{MATERIAL AND METHODS}

\section{Patients and data collection}

A single-center prospective study was conducted on fifty-four patients with newly diagnosed type 2 diabetes between June 2014 and June 2015 in Bozok University Hospital outpatient clinic. Inclusion criteria of DPP-4 inhibitor administration was the newly evidence of diabetes mellitus (DM). Diabetes diagnosis based on A1C criteria (A1C $\geq$ $6.5 \%$.) or plasma glucose criteria, either the fasting plasma glucose (FPG) (FPG $\geq 126 \mathrm{mg} / \mathrm{dL} \quad(7.0$ $\mathrm{mmol} / \mathrm{L})$ ) or the 2 -h plasma glucose (2-h PG) value after a 75 -g oral glucose tolerance test (OGTT) (2$\mathrm{h} P G \geq 200 \mathrm{mg} / \mathrm{dL}$ ( $11.1 \mathrm{mmol} / \mathrm{L})$ during an OGTT) or in a patient with classic symptoms of hyperglycemia or hyperglycemic crisis, a random plasma glucose $\geq 200 \mathrm{mg} / \mathrm{dL}(11.1 \mathrm{mmol} / \mathrm{L})^{8}$. Daily alcohol consumption above $20 \mathrm{~g}$, viral hepatitis, autoimmune hepatitis, primary sclerosing cholangitis, primer bilier cirrhosis, liver cirrhosis, or a history of hepatic surgery was excluded. 
The data was collected on age, medical history, history of drug or alcohol use, waist circumference (WC), BMI (body mass index as $\mathrm{kg} / \mathrm{m}^{2}$ ), and blood pressure (BP). After an overnight fasting standard laboratory methods including; plasma glucose, total cholesterol (t.chol), triglyceride (TG), HDLcholesterol (HDL-C), LDL-cholesterol (LDL-C), platelet count(PLT), alanine aminotransferase (ALT), aspartate amino- transferase (AST), alkaline phosphatase(AP), gamma glutamyl transferase(GGT) were measured.

In the treatment of diabetes only DPP-4 inhibitor vildagliptin were given $50 \mathrm{mg}$ twice a day without any other diabetic drug. All included patients received vildagliptin for a minimum of 6 months. As well as the patient's medical treatment, exercise and diet therapy was recommended, and diabetes education was given to all. The recommended diet programs contained daily calorie intake of $30 \mathrm{kcal}$ / ideal body weight with a protein content of $15 \%$ and fat 25\%. Minimum 120-150min was recommended as a weekly exercise. Pretreatment; each patient and / or the patient's family were informed in terms of treatment and side effects. During the treatment period, patients were seen at third and sixth months. All tests including ultrasound were repeated in each visit.

Informed consent was obtained from patients before the initiation of vildagliptin therapy. This study was approved by the Bozok University ethics committee.

\section{Nonalcoholic fatty liver disease diagnosis}

Fatty liver diagnosed by ultrasonography (USG) and performed by the same experienced radiologist. The diagnosis of NAFLD was based on increased echogenicity using ultrasound compatible with fatty infiltration of the liver with or without elevated ALT levels ${ }^{9}$. The severity of fatty liver was grouped as mild, moderate and severe.

\section{Assessment of liver steatosis and fibrosis scores}

AST/platelet ratio index (APRI), FIB-4 index and fatty liver index (FLI) were used as the noninvasive scoring systems based on several laboratory tests that help to estimate the amount of scarring in the liver ${ }^{10,11}$. The FLI calculated by an algorithm based on BMI, WC, TG and GGT had an accuracy of 0.84 (95\%CI $0.81-0.87)$ in detecting fatty liver ${ }^{11}$. APRI calculated by; [(AST / ULN AST) x 100] / Platelets (109/L). FIB-4 index is assessed as: age $(\mathrm{yr}) \times \mathrm{AST}(\mathrm{IU} / \mathrm{L}) /$ (platelet count $(109 / \mathrm{L}) \times \sqrt{\text { ALT }}(\mathrm{IU} / \mathrm{L}))^{12}$.

\section{Study design and Follow up}

The date started the monitoring of patients in the vildagliptin group was the initiation of vildagliptin therapy (i.e. June 2014) and continued to June 2015. Patients who began vildagliptin treatment were reassessed in the third and sixth months during treatment. In each visit, along with a through physical examination, biochemical tests were repeated. Also in terms of the degree of fatty liver disease, hepato-biliary system USG was assessed before and after treatment. According to initial $\mathrm{HbA} 1 \mathrm{c}$ levels patients were divided into 3 groups: those with relatively low HbA1c levels (HbAlc $<8.13 \%)$, HbA1c levels in the intermediate level (HbAlc 8.13-9.2\%), and those with higher HbAlc levels (HbA1c> 9.2\%). Patients were also divided into two groups according to liver enzymes as simple steatosis (normal liver enzymes) and NASH (elevated liver enzymes). The upper limits of normal for ALT was accepted as $30 \mathrm{IU} / \mathrm{L}$ for men and $19 \mathrm{IU} / \mathrm{L}$ for women ${ }^{10}$.

\section{Statistical analysis}

Histogram and q-q plots were generated, and the Shapiro-Wilk test was used to assess the normality of the data. Categorical data are summarized as frequencies (percentages) and continuous variables as means $( \pm \mathrm{SD})$ for parametric data or medians (range) for non-parametric data. Differences between the groups were evaluated using the unpaired Student's t-test for normally distributed variables and the Mann-Whitney $U$ test for variables with skewed distributions. The Pearson $\chi^{2}$ analysis or Fisher's exact test was used for categorical variables. Changes in variables during the follow up were analyzed by one-way repeated measurement ANOVA. Friedman test was conducted to analyze whether there is a significant change in non-parametric parameters in repeated measures. The level of statistical significance was set at $\mathrm{p}<0.05$ (two-sided). SPSS ver. 11.5 for Windows software was used to perform statistical analysis.

\section{RESULTS}

A total of 54 individuals included in the study, 35 (64.8\%) of were female and $19(35.2 \%)$ of male. The patients were in the 40-79 age range and the mean age was 55.57 years for men and 57.37 years for women. When co-morbid conditions questioned; hypertension was present in only 3 of them. All patients were examined at first visit and 3 months and 6 months after it. Pretreatment and during treatment characteristics of patients were given in Table 1. 
Table 1: Demographic and clinical characteristics during the follow-up period

\begin{tabular}{|l|l|l|l|l|}
\hline & First visit & $\begin{array}{l}\text { Second visit( }{ }^{\text {rd }} \\
\text { month })\end{array}$ & $\begin{array}{l}\text { Third visit( } 6^{\text {th }} \\
\text { month })\end{array}$ & p value \\
\hline WC(cm) & $104,90 \pm 6,84$ & $103,51 \pm 5,93$ & $103,33 \pm 6,00$ & 0,000 \\
\hline BMI(kg/m²) & $30,37 \pm 4,01$ & $30,13 \pm 4,05$ & $29,69 \pm 3,83$ & 0,000 \\
\hline AST(IU/L) & $22,09 \pm 12,14$ & $22,29 \pm 10,26$ & $20,87 \pm 7,51$ & 0,390 \\
\hline ALT(IU/L) & $30,91 \pm 26,48$ & $28,77 \pm 16,26$ & $25,94 \pm 14,80$ & 0,048 \\
\hline GGT(IU/L) & $51,48 \pm 69,60$ & $40,12 \pm 15,72$ & $39,42 \pm 20,21$ & 0,272 \\
\hline ALP(IU/L) & $70,69 \pm 17,04$ & $71,71 \pm 14,04$ & $68,11 \pm 16,28$ & 0,078 \\
\hline TG(mg/dl) & $185,88 \pm 78,47$ & $150,62 \pm 56,35$ & $171,25 \pm 71,64$ & 0,000 \\
\hline $\begin{array}{l}\text { HDL-C } \\
(\mathrm{mg} / \mathrm{dl})\end{array}$ & $43,37 \pm 8,99$ & $40,09 \pm 5,28$ & $45,20 \pm 16,94$ & 0,000 \\
\hline $\begin{array}{l}\text { LDL-C } \\
(\mathrm{mg} / \mathrm{dl})\end{array}$ & $127.74 \pm 39.05$ & $113,37 \pm 28,03$ & $108,62 \pm 34,48$ & 0,014 \\
\hline PLT(mm3) & $259,96 \pm 54,08$ & $258,11 \pm 57,46$ & $283,20 \pm 59,07$ & 0,007 \\
\hline HBA1c & $9,22 \pm 1,88$ & $7,73 \pm 4,33$ & $7,26 \pm 1,16$ & 0,000 \\
\hline FLI & $79,49 \pm 13,05$ & $75,45 \pm 12,24$ & $74,89 \pm 13,58$ & 0,000 \\
\hline APRI & $025 \pm 0,18$ & $0,23 \pm 0,15$ & $0,22 \pm 0,12$ & 0,042 \\
\hline FIB-4 & $0,93 \pm 0,32$ & $0,98 \pm 0,43$ & $0,89 \pm 0,36$ & 0,115 \\
\hline
\end{tabular}

WC: waist circumference, BMI: body mass index, AST: aspartate amino- transferase,ALT: alanine aminotransferase, GGT: gamma glutamyl transferase,ALP: alkaline phosphatase,TG: triglyceride, HDL:high density lipoprotein,LDL: low density lipoprotein,PLT: platelet count,HBAlc: glycolated hemoglobin Alc,FLI:fatty liver index,APRI: AST/platelet ratio index,FIB-4: The Fibrosis-4 score

All the patients took vildagliptin of $100 \mathrm{mg} /$ day without reduction necessitated by related sideeffects. During patients follow-up changes in WC $(\mathrm{p}=0.000)$ and BMI $(\mathrm{p}=0.000)$ were statistically significant. The mean LDL value decreased from $127.74 \pm 39.05 \mathrm{mg} / \mathrm{dl}$ to $113.82 \pm 34.48 \mathrm{mg} / \mathrm{dL}$ and the difference was statistically significant $(\mathrm{p}=$ 0.014 ). TG average value decreased from $185.88 \pm$ $78.47 \mathrm{mg} / \mathrm{dl}$ to $171.25 \pm 71.64 \mathrm{mg} / \mathrm{dL}$ and the difference was statistically significant too $(\mathrm{p}=$ 0.000). During vildagliptin treatment, ALT levels improved from $30.91 \pm 26.48$ to $25.94 \pm 14.8 \mathrm{IU} / \mathrm{L}$ $(\mathrm{P}=0.048)$ and this was more significant in female gender $(\mathrm{p}=0,027)$. HbA1c was reduced from $9.22 \%(8.07-10.35)$ to $7.26 \%(6.27-8.10)(\mathrm{P}<$ $0.001)$. FLI ( $\mathrm{p}=0,000)$ and APRI $(\mathrm{p}=0,042)$ score improved at 6 months after the initiation of vildagliptin (figure 1). There were no significant difference between patients AST, GGT, ALP, HDL and FIB-4 score before and after treatment values $(\mathrm{p}>0.05)$. 

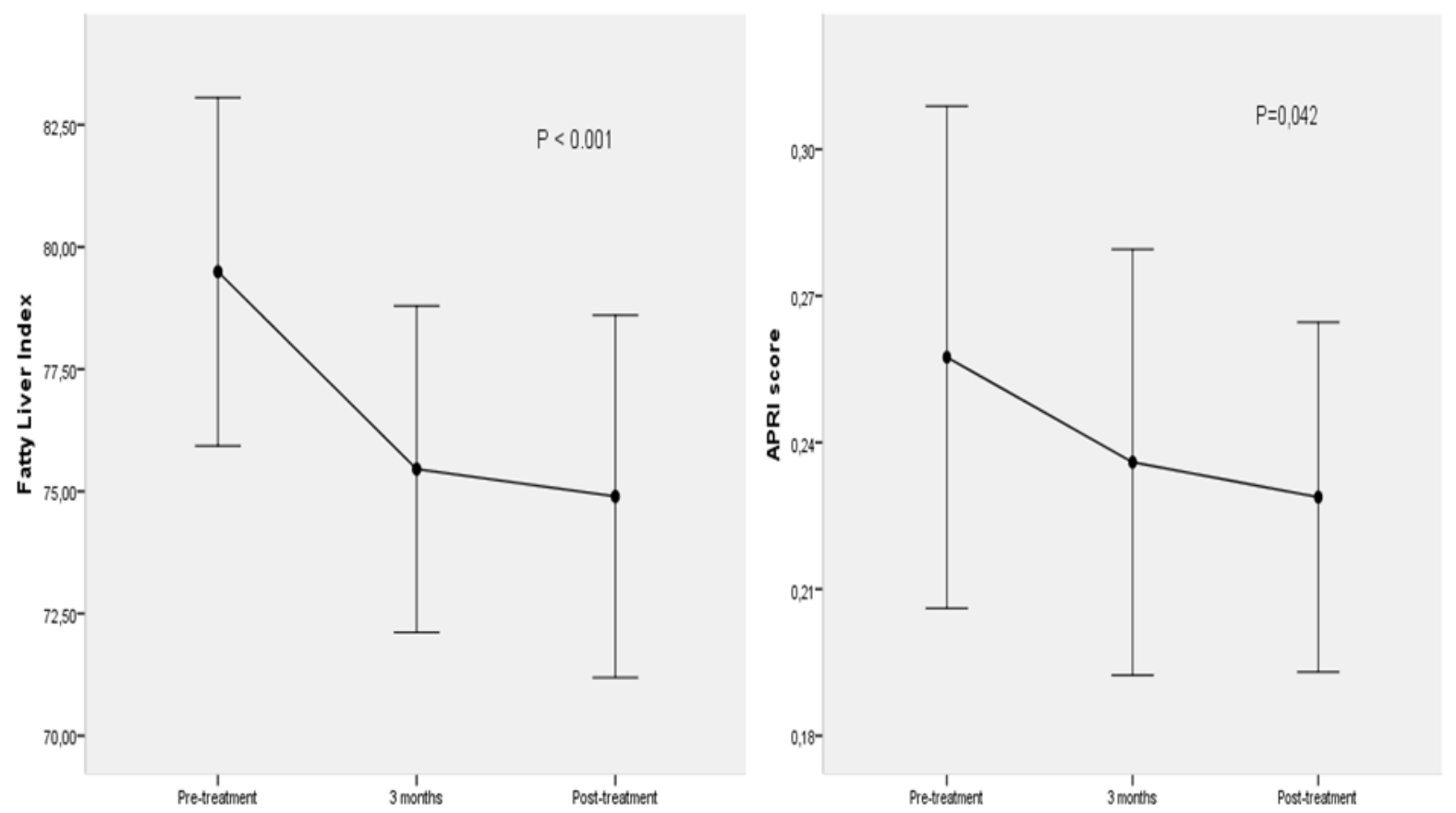

Figure 1: Alterations in FLI and APRI scores during the follow-up time of the patients

According to $\mathrm{HbA} 1 \mathrm{c}$ at baseline, at the end of 6 month, changes in AST, ALT values and FLI, APRI and FIB-4 scores were evaluated. Initially, in patients with relatively low HbA1c levels; the changes in FLI was found statistically significant $(\mathrm{p}=0.006)$. In patients with intermediate baseline HbA1c levels, changes in APRI and FIB-4 scores were statistically significant.

Twenty-seven (50\%) of individuals had steatohepatitis (NASH). In patients without NASH improvement on ALT levels were found statistically significant $(\mathrm{p}=0,014)$, there was no significant difference in terms of other parameters. In patients with NASH, improvement in FLI and APRI scores were found significant $(\mathrm{p}=0,002$, $\mathrm{p}=0,003$ respectively)(Table 2 ).

In both NAFLD and NASH groups; ALT change was more significant between $0-3$ months ( $\mathrm{p}$ value $0.002,0.030$ respectively). In both NAFLD and NASH groups, the improvement in the USG was statistically significant at the end of the 6th month ( $p$ value $0.000,0.001$ respectively). 
Table 2: The comparison of liver functions and fibrosis indexes between NAFLD and NASH group

\begin{tabular}{|c|c|c|c|c|c|}
\hline & & First visit & $\begin{array}{l}\text { Second } \\
\text { visit(3rd } \\
\text { month) }\end{array}$ & $\begin{array}{l}\text { Third visit(6th } \\
\text { month) }\end{array}$ & p value \\
\hline$\overline{\mathrm{AST}}$ & $\begin{array}{l}\text { NAFLD } \\
\text { group } \\
\text { NASH group }\end{array}$ & $\begin{array}{l}16,25 \pm 3,87 \\
27,92 \pm 14,66\end{array}$ & $\begin{array}{l}19,37 \pm 8,45 \\
25,22 \pm 11,19\end{array}$ & $\begin{array}{l}18,14 \pm 6,76 \\
23,59 \pm 7,35\end{array}$ & $\begin{array}{l}0,300 \\
0,114\end{array}$ \\
\hline ALT & $\begin{array}{l}\text { NAFLD } \\
\text { group } \\
\text { NASH group }\end{array}$ & $\begin{array}{l}18,18 \pm 5,18 \\
43,62 \pm 32,65\end{array}$ & $\begin{array}{l}22,18 \pm 8,14 \\
35,37 \pm 19,56\end{array}$ & $\begin{array}{l}19,66 \pm 7,18 \\
32,22 \pm 17,70\end{array}$ & $\begin{array}{l}0,014 \\
0,074\end{array}$ \\
\hline FLI & $\begin{array}{l}\text { NAFLD } \\
\text { group } \\
\text { NASH } \\
\text { group }\end{array}$ & $\begin{array}{l}75,77 \pm 14,53 \\
83,21 \pm 10,35\end{array}$ & $\begin{array}{l}72,49 \pm 12,87 \\
78,41 \pm 11,01\end{array}$ & $\begin{array}{l}71,16 \pm 16,16 \\
78,63 \pm 9,25\end{array}$ & $\begin{array}{l}0,062 \\
0,002\end{array}$ \\
\hline APRI & $\begin{array}{l}\text { NAFLD } \\
\text { group } \\
\text { NASH } \\
\text { group }\end{array}$ & $\begin{array}{l}0,18 \pm 0,06 \\
0,33 \pm 0,23\end{array}$ & $\begin{array}{l}0,19 \pm 0,09 \\
0,27 \pm 0,19\end{array}$ & $\begin{array}{l}0,19 \pm 0,09 \\
0,26 \pm 0,14\end{array}$ & $\begin{array}{l}0,855 \\
0,003\end{array}$ \\
\hline FIB-4 & $\begin{array}{l}\text { NAFLD } \\
\text { group } \\
\text { NASH group }\end{array}$ & $\begin{array}{l}0,90 \pm 0,34 \\
0,95 \pm 0,30\end{array}$ & $\begin{array}{l}1,01 \pm 0,52 \\
0,95 \pm 0,33\end{array}$ & $\begin{array}{l}0,89 \pm 0,39 \\
0,88 \pm 0,34\end{array}$ & $\begin{array}{l}0,163 \\
0,495\end{array}$ \\
\hline
\end{tabular}

AST: aspartate amino- transferase,ALT: alanine amino- transferase, FLI:fatty liver index,APRI: AST/platelet ratio index,FIB-4: The Fibrosis-4 score

Table 3: Changes in FLI and APRI scores in all patients. Error bars represents 95\% CI.

\begin{tabular}{|l|l|l|l|l|}
\hline & First visit & $\begin{array}{l}\text { Second visit( } 3^{\text {rd }} \\
\text { month) }\end{array}$ & Third visit( $6^{\text {th }}$ month) & p value \\
\hline WC & $104,90 \pm 6,84$ & $103,51 \pm 5,93$ & $103,33 \pm 6,00$ & 0,000 \\
\hline BMI & $30,37 \pm 4,01$ & $30,13 \pm 4,05$ & $29,69 \pm 3,83$ & 0,000 \\
\hline AST & $22,09 \pm 12,14$ & $22,29 \pm 10,26$ & $20,87 \pm 7,51$ & 0,390 \\
\hline ALT & $30,90 \pm 26,48$ & $28,77 \pm 16,26$ & $25,94 \pm 14,80$ & $0,045 /$ \\
\hline GGT & $51,48 \pm 69,60$ & $40,12 \pm 15,72$ & $39,42 \pm 20,21$ & 0,000 \\
\hline ALP & $70,69 \pm 17,04$ & $71,71 \pm 14,04$ & $68,11 \pm 16,28$ & 0,272 \\
\hline TG & $185,88 \pm 78,47$ & $150,62 \pm 56,35$ & $171,25 \pm 71,64$ & 0,078 \\
\hline HDL & $43,37 \pm 8,99$ & $40,09 \pm 5,28$ & $45,20 \pm 16,94$ & 0,000 \\
\hline LDL & $123,91 \pm 38,13$ & $113,37 \pm 28,03$ & $108,62 \pm 34,48$ & 0,000 \\
\hline PLT & $259,96 \pm 54,08$ & $258,11 \pm 57,46$ & $283,20 \pm 59,07$ & 0,303 \\
\hline HBA1C & $9,22 \pm 1,88$ & $7,73 \pm 4,33$ & $7,26 \pm 1,16$ & 0,007 \\
\hline FLI & $79,49 \pm 13,05$ & $75,45 \pm 12,24$ & $74,89 \pm 13,58$ & 0,000 \\
\hline APRI & $025 \pm 0,18$ & $0,23 \pm 0,15$ & $0,22 \pm 0,12$ & 0,000 \\
\hline FIB4 & $0,93 \pm 0,32$ & $0,98 \pm 0,43$ & $0,89 \pm 0,36$ & 0,042 \\
\hline
\end{tabular}


Table 4: Evaluation of AST, ALT, FLI, APRI and FIB4 parameters before and after treatment according to NAFLD and NASH groups.

\begin{tabular}{|c|c|c|c|c|}
\hline & First visit & $\begin{array}{l}\text { Second visit(3rd } \\
\text { month) }\end{array}$ & $\begin{array}{l}\text { Third visit(6th } \\
\text { month) }\end{array}$ & $\mathrm{p}$ value \\
\hline $\begin{array}{l}\text { AST NAFLD } \\
\text { group } \\
\quad \text { NASH group }\end{array}$ & $\begin{array}{l}16,25 \pm 3,87 \\
27,92 \pm 14,66\end{array}$ & $\begin{array}{l}19,37 \pm 8,45 \\
25,22 \pm 11,19\end{array}$ & $\begin{array}{l}18,14 \pm 6,76 \\
23,59 \pm 7,35\end{array}$ & $\begin{array}{l}0,300 \\
0,114\end{array}$ \\
\hline 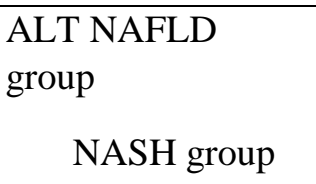 & $\begin{array}{l}18,18 \pm 5,18 \\
43,62 \pm 32,65\end{array}$ & $\begin{array}{l}22,18 \pm 8,14 \\
35,37 \pm 19,56\end{array}$ & $\begin{array}{l}19,66 \pm 7,18 \\
32,22 \pm 17,70\end{array}$ & $\begin{array}{l}0,014 \\
0,074\end{array}$ \\
\hline $\begin{array}{l}\text { FLI NAFLD } \\
\text { group } \\
\quad \text { NASH group }\end{array}$ & $\begin{array}{l}75,77 \pm 14,53 \\
83,21 \pm 10,35\end{array}$ & $\begin{array}{l}72,49 \pm 12,87 \\
78,41 \pm 11,01\end{array}$ & $\begin{array}{l}71,16 \pm 16,16 \\
78,63 \pm 9,25\end{array}$ & $\begin{array}{l}0,062 \\
0,002\end{array}$ \\
\hline $\begin{array}{l}\text { APRI NAFLD } \\
\text { group } \\
\quad \text { NASH group }\end{array}$ & $\begin{array}{l}0,18 \pm 0,06 \\
0,33 \pm 0,23\end{array}$ & $\begin{array}{l}0,19 \pm 0,09 \\
0,27 \pm 0,19\end{array}$ & $\begin{array}{l}0,19 \pm 0,09 \\
0,26 \pm 0,14\end{array}$ & $\begin{array}{l}0,855 \\
0,003\end{array}$ \\
\hline $\begin{array}{l}\text { FIB4 NAFLD } \\
\text { group } \\
\quad \text { NASH group }\end{array}$ & $\begin{array}{l}0,90 \pm 0,34 \\
0,95 \pm 0,30\end{array}$ & $\begin{array}{l}1,01 \pm 0,52 \\
0,95 \pm 0,33\end{array}$ & $\begin{array}{l}0,89 \pm 0,39 \\
0,88 \pm 0,34\end{array}$ & $\begin{array}{l}0,163 \\
0,495\end{array}$ \\
\hline
\end{tabular}

\section{DISCUSSION}

This study showed for the first time in the literature that vildagliptin treatment, regulates blood sugar as well as have beneficial effects on the progression of the liver disease on newly diagnosed diabetes patients with NAFLD. Significant improvement achieved in FLI and APRI at the end of the sixth month treatment, showing the degree of hepatic steatosis and pointing the fibrosis, respectively. Patients showed improvement for ALT and fatty liver severity by USG after vildagliptin treatment. Improvement on ALT levels was found statistically significant in patients without steatohepatitis. FLI and APRI scores were found significantly decreased in individuals with steatohepatitis. Another important point; no adverse effects or noncompliance to medication was observed. This study emphasized that; vildagliptin treatment can be used reliably in diabetes patients with NAFLD.

In NAFLD and NASH; impaired fatty acid oxidation and insulin resistance is characteristic and therefore considered to be liver components of the metabolic syndrome ${ }^{13}$. A high fat diet, denovo lipogenesis or peripheral-visceral lipolysis results in increased hepatic flow of free fatty acids 14. When organs do not stimulate their own oxidation the free fatty acid release excessively increasing not only in adipose tissue; also in the liver, in the heart and muscles; and this results in lipotoxicity and insulin resistance. Saxagliptin (daily dose of $10 \mathrm{mg} / \mathrm{kg}$ ) was given for 8 weeks to rat models of NAFLD and type 2 diabetes and was shown to have positive effects on blood glucose and HOMA-IR, liver functions and superoxide dismutase activity but no significant improvement was found on AST levels. Good therapeutic efficacy of saxagliptin treatment in fatty liver was connected to significantly decrease in hepatic oxidative stress and hepatocyte damage, and regulation of the expression of apoptosis-related proteins ${ }^{15}$. During 12 months of alogliptin treatment on 39 patients with NAFLD, disease progression was evaluated with NAFIC scores were found improved [non-alcoholic steatohepatitis (NASH), ferritin, insulin and type IV collagen $7 \mathrm{~S}$ ] and also reduction in HbA1c ${ }^{16}$. Our study results also showed improvement on fatty liver severity, liver enzymes and fibrosis score 
along with insulin resistance after vildagliptin treatment.

The serum DPP IV activity was found higher in biopsy proven NASH patients $(57.3+/-7.8 \mathrm{U} / \mathrm{L})$ than controls $(43.6+/-10.6 \mathrm{U} / \mathrm{L})$ and the intensity of CD26 immunostaining was correlated with histopathological grade ${ }^{17}$. Yilmaz et al. presented as a hypothesis that weight loss with improvement in elevated liver enzyme abnormalities and hepatocytes ballooning but, no change in fibrosis were achieved after 12 months of treatment with sitagliptin in their study on type 2 diabetes individuals who are also diagnosed NASH with biopsy ${ }^{18}$. These findings indicate that DPP-IV has a direct role in the pathophysiology of NASH, and the use of DPP-IV inhibitors could prevent the progression of hepatic steatosis and inflammation ${ }^{18}$. In the direction of these results, our study showed significant improvement in FLI scores and severity of fatty liver. As we did not observed improvement at liver enzymes in NASH patients, statistically significant improvement was achieved in liver fibrosis index in both NAFLD and NASH patients.

The inhibition of DPP-4 was shown to avoid significantly infiltration of macrophages in adipose tissue and decreased release of plasminogen activator inhibitor-1 and prevented fatty liver ${ }^{20}$. Kaji et al showed that DPP IV-I inhibits the liver fibrosis and also the production of liver transforming growth factor- $\beta 1$ (TGF- $\beta 1)^{21}$. They also found that active hepatic stellate cells (HSC) function is suppressed under the DPP-4 inhibitors antifibrotic effects. Although high glucose and insulin levels induce HSC proliferation in a dose dependent manner; DPP IV-I seems to be more effective against NASH at low glucose levels ${ }^{22-24}$. Compatible with these findings, our results showed that patients with low and moderately elevated HbA1C levels were more prone to benefit from vildagliptin treatment. Along with these studies, DPP IV inhibition might have beneficial effects not only on insulin resistance but also direct effect on hepatic steatosis and injury.

The present study has several limitations. Diagnosis of NAFLD was done by using ultrasonography and liver injury by a non-invasive scoring systems. Although liver biopsy known as the best method in NAFLD diagnosis and to determine disease progression; implementation of biopsy to each patient with type 2 diabetes for diagnosis of NAFLD and liver injury is not possible and a realistic approach. ${ }^{25}$. It is a single arm study. There was no placebo arm to compare whether the end of treatment results is purely attributable to the vildagliptin or they are the results of the variations observed throughout the natural course of the disease.

In conclusion, we tried to emphasize the impact of DPP IV-I administration on the progression of NAFLD in diabetic patients. Vildagliptin treatment has beneficial effects on the progression of the liver disease with no adverse effects. We suggest that DPP IV-I treatment can be a new treatment strategy in NAFLD progression in NAFLD patients with type 2 diabetes in the near future.

\section{REFERENCES}

1. Williams, C.D., et al., Prevalence of nonalcoholic fatty liver disease and nonalcoholic steatohepatitis among a largely middle-aged population utilizing ultrasound and liver biopsy: a prospective study. Gastroenterology, 2011. 140(1): p. 124-31.

2. Ceriello, A., et al., DPP-4 inhibitors: pharmacological differences and their clinical implications. Expert Opin Drug Saf, 2014. 13 Suppl 1: p. S57-68.

3. Drucker, D.J. and M.A. Nauck, The incretin system: glucagon-like peptide-1 receptor agonists and dipeptidyl peptidase- 4 inhibitors in type 2 diabetes. Lancet, 2006. 368(9548): p. 1696-705.

4. Matikainen, N., et al., Vildagliptin therapy reduces postprandial intestinal triglyceride-rich lipoprotein particles in patients with type 2 diabetes. Diabetologia, 2006. 49(9): p. 2049-57.

5. Derosa, G., et al., Vildagliptin compared to glimepiride on post-prandial lipemia and on insulin resistance in type 2 diabetic patients. Metabolism, 2014. 63(7): p. 957-67.

6. Ahren, B., et al., Improved meal-related betacell function and insulin sensitivity by the dipeptidyl peptidase-IV inhibitor vildagliptin in metformin-treated patients with type 2 diabetes over 1 year. Diabetes Care, 2005. 28(8): p. 1936-40.

7. Mari, A., et al., Vildagliptin, a dipeptidyl peptidase-IV inhibitor, improves modelassessed beta-cell function in patients with type 2 diabetes. J Clin Endocrinol Metab, 2005. 90(8): p. 4888-94.

8. Association, A.D., 2. Classification and diagnosis of diabetes. Diabetes care, 2015. 38(Supplement 1): p. S8-S16.

9. Fracanzani, A.L., et al., Carotid artery intimamedia thickness in nonalcoholic fatty liver disease. Am J Med, 2008. 121(1): p. 72-8. 
10.Subasi, C.F., U.E. Aykut, and Y. Yilmaz, Comparison of noninvasive scores for the detection of advanced fibrosis in patients with nonalcoholic fatty liver disease. Eur $\mathbf{J}$ Gastroenterol Hepatol, 2015. 27(2): p. 137-41.

11.Bedogni, G., et al., The Fatty Liver Index: a simple and accurate predictor of hepatic steatosis in the general population. BMC Gastroenterol, 2006. 6: p. 33.

12.Martinez, S.M., et al., Noninvasive assessment of liver fibrosis. Hepatology, 2011. 53(1): p. 325-35.

13.Ali, R. and K. Cusi, New diagnostic and treatment approaches in non-alcoholic fatty liver disease (NAFLD). Ann Med, 2009. 41(4): p. 265-78.

14.Marra, F., et al., Molecular basis and mechanisms of progression of non-alcoholic steatohepatitis. Trends Mol Med, 2008. 14(2): p. 72-81.

15.Liu, Y., et al., [Therapeutic effect of saxagliptin in rat models of nonalcoholic fatty liver and type 2 diabetes]. Nan Fang Yi Ke Da Xue Xue Bao, 2014. 34(6): p. 862-8.

16.Mashitani, T., et al., Efficacy of alogliptin in preventing non-alcoholic fatty liver disease progression in patients with type 2 diabetes. Biomed Rep, 2016. 4(2): p. 183-187.

17.Balaban, Y.H., et al., Dipeptidyl peptidase IV (DDP IV) in NASH patients. Ann Hepatol, 2007. 6(4): p. 242-50.
18. Yilmaz, Y., et al., Dipeptidyl peptidase IV inhibitors: therapeutic potential in nonalcoholic fatty liver disease. Med Sci Monit, 2009. 15(4): p. HY1-5.

19.Macauley, M., et al., Effect of vildagliptin on hepatic steatosis. J Clin Endocrinol Metab, 2015. 100(4): p. 1578-85.

20.Shirakawa, J., et al., Diet-induced adipose tissue inflammation and liver steatosis are prevented by DPP-4 inhibition in diabetic mice. Diabetes, 2011. 60(4): p. 1246-57.

21.Kaji, K., et al., Dipeptidyl peptidase-4 inhibitor attenuates hepatic fibrosis via suppression of activated hepatic stellate cell in rats. J Gastroenterol, 2014. 49(3): p. 481-91.

22.Kaji, K., et al., Impact of insulin resistance on the progression of chronic liver diseases. Int $\mathbf{J}$ Mol Med, 2008. 22(6): p. 801-8.

23.Ben-Shlomo, S., et al., Glucagon-like peptide-1 reduces hepatic lipogenesis via activation of AMP-activated protein kinase. J Hepatol, 2011. 54(6): p. 1214-23.

24.Svegliati-Baroni, G., et al., Glucagon-like peptide-1 receptor activation stimulates hepatic lipid oxidation and restores hepatic signalling alteration induced by a high-fat diet in nonalcoholic steatohepatitis. Liver Int, 2011. 31(9): p. 1285-97.

25.Machado, M.V. and H. Cortez-Pinto, Noninvasive diagnosis of non-alcoholic fatty liver disease. A critical appraisal. J Hepatol, 2013. 58(5): p. 1007-19. 